\title{
Different mechanisms, same result: Remembering the liberation war in Mozambique
}

Memory Studies

$1-17$

(C) The Author(s) 2021

Article reuse guidelines: sagepub.com/journals-permissions DOI: $10.1177 / 1750698021995993$ journals.sagepub.com/home/mss

@SAGE

\author{
Natália Bueno \\ Centre for Social Studies of the University of Coimbra, Portugal
}

\begin{abstract}
Even though scholars have made substantial contributions in connecting the fields of transitional justice and memory studies, important questions remain unanswered. The question of sequencing is one of them. How does a certain TJ mechanism condition the implementation of subsequent mechanisms and how together they shape memory narratives in a given society? This article builds on the case of Mozambique. Soon after the signing of the General Peace Agreement in 1992, the Frelimo-led government approved Amnesty Law I5/92 and with it, the past was to be left in the past. Such a choice was different from the one taken by Samora Machel—Mozambique's first president-between 1975 and 1982. By promoting a quasi-truth commission, Machel revisited Mozambique's colonial past and brought comprometidos' actions into the open. This article finds that whether the government opened up about the past or sought to leave it behind, the result has been the same: the celebratory reproduction of the liberation war narrative. Resorting to path dependence and critical junctures, this study explains the ways in which such a narrative has become hegemonic throughout the last four decades.
\end{abstract}

\section{Keywords}

colonial war, critical junctures, memory, Mozambique, path dependence, transitional justice

\section{Introduction}

The scarcity of studies connecting transitional justice (TJ) and memory that characterized the early 2000 s is no longer observable. Not to mention numerous articles, a series of books have delved into questions dear to both fields, advancing the interrelationship between them. On the one hand, some scholars have taken up the challenge to historicize the political memories of entire regions such as Latin America (see e.g. Allier and Crenzel, 2015). On the other hand, some scholars have focused on within-case analyses to understand top-down and bottom-up dynamics of transitional justice and their relationship with memory (see e.g. Conley, 2019; Sokolić, 2019).

However, despite this enormous advancement, many questions connecting both fields still remain unexplored and open to debate. The way transitional justice mechanisms (TJMs) have been

\section{Corresponding author:}

Natália Bueno, Centre for Social Studies of the University of Coimbra, Colégio da Graça, Rua da Sofia, I36-I38, 3000-

389 Coimbra, Portugal.

Email: nataliabueno@ces.uc.pt 
ordered across time - or, in other words, their sequencing — and how together they affect memory narratives is one of these questions. Exception applies particularly to the work of Francesca Lessa (2013) in which she uses the logic of critical junctures to help understand modifications in TJ and memory narratives across time. According to her, "critical junctures do not necessarily generate new TJ mechanisms or memory narratives but rather account for why they evolve and change across time" (Lessa, 2013: 9).

Joining the effort to better understand the relationship between TJ and memory, ${ }^{1}$ specifically with regard to the ways in which TJMs shape memory narratives, this article builds on the case of Mozambique. But unlike previous studies, I resort to two explanatory logics to construct this analysis: critical junctures and path dependence-logics largely used in the field of historical analysis and further detailed below.

Mozambique became independent in the aftermath of a 10-year liberation war, from 1964 to 1974. ${ }^{2}$ Such a conflict happened almost in parallel to the Portuguese colonial wars also fought in Angola (1961-1974) and Guinea-Bissau (1964-1974) which came to symbolize "the last breath of an already anachronistic Empire" (Cardina and Martins, 2019: 114). In particular, the Mozambican liberation war unfolded mainly in the northern provinces of the country and had the Frente de Libertação de Moçambique (Frelimo) as the major player on the front line against Portugal. Following a short period of transition in which the country's administration was shared by both sides, Portuguese and Mozambicans officials, Mozambique finally became independent on 25 June 1975. As required by Samora Machel, this emblematic moment happened on the same day Frelimo was formed, ${ }^{3}$ only 13 years later, inaugurating the juxtaposition of Mozambique and Frelimo's histories. The ceremony of the proclamation of independence was held at the Machava football stadium where Machel, at the time president of Frelimo, became the president of Mozambique as well.

Among the many pressing post-independence issues was the question of what action to take against the comprometidos or the compromised, that is, "Mozambicans who during the colonial period belonged to or were linked to political, ideological, administrative, military, and police organizations of the Portuguese colonial system" (Notícias, 1982b), such as PIDE (International Police for the Defense of the State) and the Portuguese colonial army. ${ }^{4}$ After some time of indecisiveness, the ruling Frelimo party finally "c[a]me up with an approach that relie[d] on social pressure and self-criticism, rather than on prisons and sanctions" (IHT, 1979). Supposedly inspired by a Chinese method of public-shaming, Frelimo ordered the pictures of the compromised to be posted on their workplaces together with an explanation of what they had done. The pictures remained in place for a period of nearly 4 years at the end of which Machel himself coordinated the Meeting of the Compromised. ${ }^{5}$ Understood as a quasi-truth commission for it does not fulfil all required elements of a truth commission, ${ }^{6}$ these meetings were held in 1982 during the months of May and June, and brought together more than a thousand people (Sopa, 2001). They were characterized by a series of Q\&As presided by Machel during which the comprometidos talked about their past experiences. "It's only by reviewing the past [that] will we know the present. Only by knowing the present [that] will we have a perspective for the future" (Machel, 1982) voiced Machel in his inaugural speech for the Reunião dos Comprometidos on 10 May 1982.

This process of 'public acknowledgement of the past' and search for 'the truth' (Borges Coelho, 2003; Igreja, 2010; Meneses, 2016) differed considerably from the logic of 'leaving the past behind' distinctive of the post-civil war period. Despite the lack of consensus about its causes and whether it was a civil war or not (1976-1992), ${ }^{7}$ the fact is that Mozambican society added 16 more years to its devastating war résumé. While the number of war-related deaths was close to one million (Hanlon, 1991), 1.5 million were forcibly displaced and made refugees in the neighboring countries due to the horrors provoked by both sides, Frelimo and the Resistencia Nacional Moçambicana (Renamo) (Igreja, 2008; Schafer, 2007; Wiegink, 2013). 
In the aftermath of this armed conflict, however, neither a call for investigations nor for the punishment of those responsible for the human rights violations and war crimes committed during this fighting were made. Following the signing of the General Peace Agreement (GPA) on 4 October 1992, the Frelimo-led government passed Amnesty law 15/92 that exempted members of both sides from the crimes and abuses committed from 1979 to 1992 (BR, 1992). In unison, Joaquim Chissano and Afonso Dhlakama, former leaders of Frelimo and Renamo, respectively, urged the Mozambican people to leave the past alone and reconcile. To start anew, people were advised to "replace hatred with understanding and solidarity, revenge with forgiveness and tolerance, distrust with brotherhood and friendship" (Notícias, 1992).

Applying the logic of critical junctures to Mozambique's violent past, I identify two of them. First, the country's independence in 1975, and, second, the end of the civil war between Frelimo and Renamo in 1992. These moments epitomize the intricate relationship between a bellicose past, the implementation of mechanisms to deal with it, and political leaders' pursuit for political legitimacy. As briefly explained, the Mozambican political leaders adopted particular approaches toward the past in each of these occasions. While during the former they opted to revisit the past through a quasi-truth commission, on the latter they chose to leave it behind by enacting a general amnesty. The immediate question that arises is whether these moments of transition and their TJMs have shaped Mozambique's memory narratives across time as to explain their shifts and/or variations.

As Jelin (2003: 33-34) reminds us, the emergence of multiple narratives results from the agency of "memory entrepreneurs," that is, those "who seek social recognition and political legitimacy of one (their own) interpretation or narrative of the past." During and in the aftermath of traumatic events such as dictatorships and war, "it is impossible to find one memory, or a single vision and interpretation of the past shared throughout society" (Jelin, 2003: xviii). This multiplicity of memory narratives does not entail, however, that they acquire equal levels of legitimacy or appeal within a given society at any given moment. What we observe in fact is that more often than not "a single script of the past [becomes] widely accepted, or even hegemonic" (Jelin, 2003: xviii) in spite of the existence of memories capable of challenging it, that is, despite the existence of counter-memories. ${ }^{8}$

The analysis of the Mozambican case shows that whether opening up about the past or seeking to leave it behind, the result has been the same: the remembering of the liberation war narrative. As any other memory narrative, Frelimo's celebratory account of the liberation war has not remained completely static, undergoing small variations every time it was retold. Yet these dynamics of change did not preclude it from becoming the official, hegemonic memory narrative about Mozambique's struggle against colonialism for the last 40 years. This finding is significant because besides challenging the existing claims in the literature about critical junctures and their effects on memory narratives, it brings to light a new element: path dependence. While critical junctures (and their respective TJMs) might favor change, one must not underestimate path dependence's capacity to overpower it with its inertia or self-reinforcing nature.

In the remainder of this article, I turn first to memory studies, historical analysis, and transitional justice to delineate the potential explanatory power resulting from the interrelationship between these fields. I argue that critical junctures and path dependence are valuable tools in explaining the interactions between TJ and memory narratives across time. More specifically, I suggest that understanding sequencing in the case of $\mathrm{TJ}$ and memory narratives requires taking into account the dynamics generated by both critical junctures and path dependence. I then apply this theoretical framework to the case of Mozambique in the third and fourth sections. While the third section is dedicated to the first critical juncture - the independence in 1975- the fourth is centered on the second one- the end on the civil war in 1992. By doing that, I show how the quasi-truth commission implemented in 1982 and the amnesty law implemented in 1992 have shaped the 
liberation war narrative in Mozambique. As a result, I find that whether the government opened up about the past or sought to leave it behind, the result has been the same: the celebratory reproduction of the liberation war narrative. A narrative that has become hegemonic, helping Frelimo to legitimize its dominant status for more than four decades. The final section resumes the argument and presents some concluding remarks.

\section{Adding path dependence to the $\mathrm{TJ}$ and memory equation}

Unlike other scholars that have explored the mutual shaping relationship between $\mathrm{TJ}$ and memory (Lessa, 2013) or focused on a particular mechanism (Andrews, 2003), the present work pays attention to the ways in which different and subsequent TJMs, namely a quasi-truth commission and an amnesty, have shaped memory narratives across time. ${ }^{9}$ In other words, the goal is to observe how the Meeting of the Compromised and the Amnesty Law 15/92 have functioned as channels of memory by outlining which stories were told (and concomitantly which were silenced) and how they should be interpreted. To this matter, an observation follows. Since the mechanisms under analysis were implemented by the state, this work centers primarily on the role state agents have played as "memory entrepreneurs." Yet taking into account their relevance in acting in response to those state agents, attention is also devoted to minor and/or oppositional groups that have supported alternative narratives of the past. ${ }^{10}$

In analyzing these mechanisms and their impact on memory narratives, it is also important to understand the context in which they have emerged. This is when critical junctures come to the picture. In their seminal work, Ruth Collier and David Collier (2002: 27) defined critical junctures as "transitions [that] establish certain directions of change and foreclose others in a way that shapes politics for years to come." In a more recent work, Hillel Soifer suggested that a critical juncture should be seen as "[a] potential turning point 'at which the interlocked networks of relation that preserve stability come unglued and the (normal) perpetual change of social life takes over'" (Abbot, 2001: 259; Soifer, 2012: 1574). Idiosyncrasies aside, one could argue that critical junctures are moments of change that take place within certain windows of opportunity. In this sense, moments such as those experienced in Mozambique - independence and end of civil war-rightly fit the bill of critical junctures. They were periods like no others in the country's postcolonial history characterized by major changes in the political, economic, social, and cultural spheres that shaped Mozambican society for years to come.

The use of critical junctures to understand memory narratives shifts is not necessarily new. In her work about TJ and memory in Argentina and Uruguay, Lessa (2013) utilizes critical junctures to explain both the alterations of TJ policies and memory narratives in those countries across time. According to her, critical junctures help "to sketch the trajectory of TJ mechanisms and memory narratives, tracking the moments in which a change takes place, and understand this evolution in the long term" (Lessa, 2013: 28). In particular, critical junctures help to identify the moments of change in what she understands as a mutually shaping constitutive relationship between memory and transitional justice policies. While coinciding with Lessa with regard to the relevance of critical junctures to understand the interrelations between TJ and memory, the present analysis adds a twist by calling attention to an equally important element: path dependence, or more broadly, to the fact that 'history matters.'

Rather than immutable, the past is a malleable narrative as it is revisited and rewritten every now and then. This does not mean, however, that it can be freely manipulated, with no obstacles to its reconstruction (Aguilar, 2002; Schudson, 1992). Sensitive to this understanding, I argue that to better understand memory narratives shifts is also important to take into account the ways in which they are reproduced. While on the one hand critical junctures are seen as windows of opportunities 


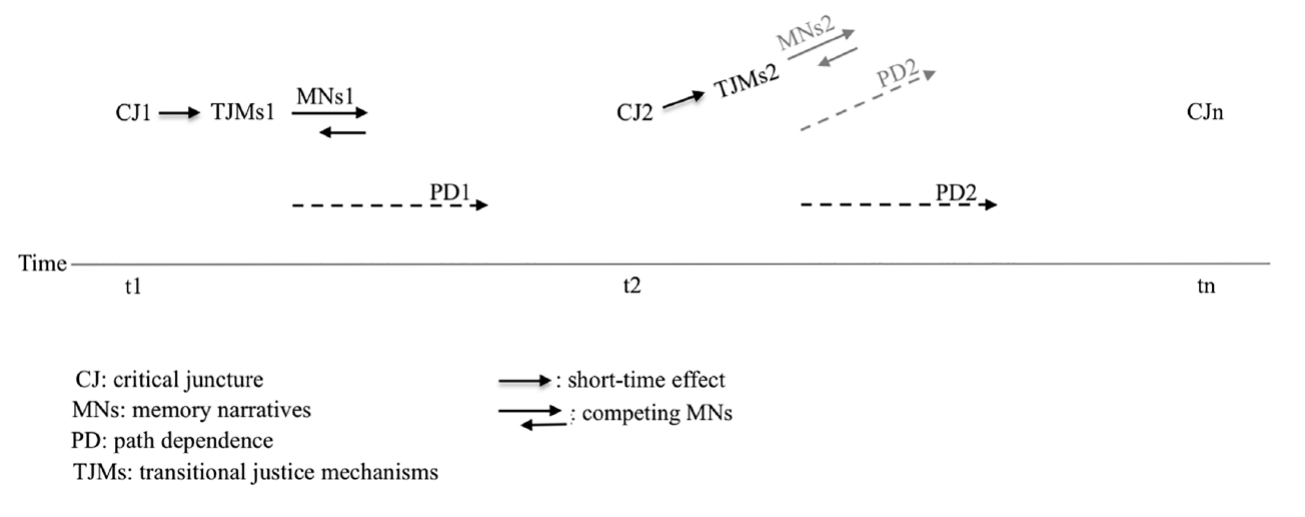

Figure I. Critical junctures, path dependence, and time.

Source: Elaborated by the author.

for change, on the other hand path dependence is understood as "historical sequences in which contingent events set into motion institutional patterns or event chains that have deterministic properties" (Mahoney, 2000: 507). Two elements deserve special attention in this definition. First, these historical sequences are causal, that is, they lead to a particular outcome (in our case the reproduction of the liberation war narrative). Second, they launch specific institutional patterns that can have a self-reinforcing nature or inertia, reproducing themselves across time. Together these aspects help to reveal how memory narratives are conceived and reproduced across time.

Translating the logics of critical junctures and path dependence to the study of TJ and memory, whereas the former facilitates the identification of moments in which institutional elements are eased, favoring transformations, the latter helps to pin down the institutional elements that remain in place, hindering those transformations. These elements are key when examining the question of sequencing, or in other words, the way a certain TJM condition the implementation of subsequent mechanisms and how together they shape memory narratives in a given society. Figure 1 below graphically illustrates this understanding. In t1, critical juncture 1 opens the first window of opportunity for change. The mechanism(s) implemented during this period help(s) to generate specific institutional patterns (in our case memory narratives) that, due to their self-reinforcing nature, are reproduced across time, conforming a path-dependent sequence. In $\mathrm{t} 2$, critical juncture 2 opens the second window of opportunity for change. Alike in the first critical juncture, the mechanisms created during this period also have the potential to generate specific institutional patterns. This time, however, one needs to take into account the institutional patterns already in place and whether they are overpowered or able to overpower any attempts of change. If the current institutional patterns are overpowered, a different path-dependent sequence is created. If they overpower, the earlier sequence is maintained. The same reasoning applies up to $t_{n}-C_{n}$, $n$ varying for each case depending on the number of critical junctures present. Figure 1 also depicts the struggle between different versions of the past characteristic of societies tainted by traumatic events as suggested before. This representation is relevant for two reasons. First, it denotes the agency of memory entrepreneurs - regardless of their status as state agents (in our case Frelimo and its members) or opposition groups - in developing and reproducing competing memory narratives. Second, it shows that such a struggle also accounts for the resulting pathdependent trajectory taken as well as to its slight variations along the way as the application of this framework to the Mozambican case later demonstrates. 


\section{Independence: Setting in motion the remembering of the liberation war}

The critical juncture that had been opened with Mozambique's independence in 1975 gained special contours when, following the national campaign for the restructuring of Frelimo in November 1978, its high-ranking leaders opted for the public-shaming strategy. In its entirety, the process of identifying and revisiting the comprometidos ' past lasted for nearly 4 years coming to a close with the meetings held in 1982. "Our power is not revengeful or vindictive" (Machel, 1982) claimed Machel when giving the reasons why Frelimo had decided for such strategies. "In other countries, you [the compromised] would had been tried or shot" observed Machel (1982) as to emphasize Frelimo's practices of clemency toward the compromised.

Another crucial element was the comprometidos' connection with their own past. According to Machel, their reintegration and transformation into full Mozambicans implied the public acknowledgement of their past actions. Such an exercise would be the first effort to break them away from the burden weighting on their consciences (Machel, 1982). Different from the ex-political prisoners ${ }^{11}$ clandestine Frelimo members who allegedly collaborated with the Portuguese after being imprisoned and tortured - the compromised included those who had voluntarily worked for the Portuguese. In other words, the compromised "were those who had given in the temptation, having committed themselves to the colonial system" (Meneses, 2016: 161). For that reason, to expose the comprometidos' past was so essential. The logic was that by bringing their secrets to the open, 'the enemy' would have no way to get back to them as blackmailing, among other methods, would no longer be an option.

To show willingness to change was also indispensable. "Compromised or compatriots?" (Notícias, 1982a) voiced Machel repeatedly during the meetings as to distinguish those who had reflected on their "unpatriotic" past deeds from those who were still subjects of the enemy and in need of "mental decolonization" in order to become full Mozambicans (Machel, 1982). Besides its use as an instrument of persuasion, Machel's question also mirrored two foundational logics of Frelimo's discourse: the idea of the enemy and of the new man. ${ }^{12}$

As José Luis Cabaço (2001: 105) asserted,

[. . .] the experience of the politico-military struggle of the Mozambique Liberation Front in the 1960s was essential in forming the thought of Frelimo and of Samora Machel. In this period, divergent positions arose on several questions [. . . ] but in the final analysis, it was always the definition of the enemy the central problem that was under discussion.

But more than the central issue of endless debates and fratricidal conflicts, the idea of the enemy has functioned as a guiding principle of the "main direction of the struggle" (Cabaço, 2001: 105) since Frelimo's early stages. ${ }^{13}$ As Machel invariably remarked in his speeches, "the struggle continues." 14 Having defeated colonialism, it was also essential "to wage a constant battle against all divisive situations and tendencies" (Machel, 1975). Such tendencies included, for instance, the nostalgia of the colonial times, characteristic of those who still had not accepted that independence was irreversible (Machel, 1982).

As Frelimo had defeated the external enemy, the 'main direction of the struggle' became the internal one as more attention was given to the (mis)deeds of Mozambicans. In this context, the Meeting of the Compromised helped Frelimo to identify who was with them and who was not. Upholding the norm used so far, whoever was considered as a non-Frelimo supporter, was automatically labeled as an enemy. ${ }^{15}$

While on the one hand those new "enemies" were being identified, on the other hand Machel (1982) was giving emphasis to people's capacity for transforming themselves and becoming active agents, or in other words, of becoming "new men." As the notion of enemy with its roots in the 
liberation war was adapted to the new realities of post-independence Mozambique, so was the notion of what meant to be Mozambican. As Machel declared,

Politico-military training was the forging of national unity, of common thinking, and of patriotic and class awareness. We came in as Macondes, Macuas, Nyanjas, Nhungues, Manicas, Changanas, Ajauas, Rongas or Senas, but we came out of it as Mozambicans. We came in as blacks, whites, mulattoes or Indians, but we came out of it as Mozambicans. When we arrived, we brought with us vices, defects, greed, liberalism, and elitism. We destroyed the negative values, the reactionary values. We learnt to carry with us the habits and behavior of a Frelimo militant (Machel, 1981 apud Cabaço, 2001: 105).

Therefore, to be Mozambican one was supposed to abandon his/her old self-which beyond his/ her ethnic origins also included any colonialist, bourgeois, and individualist values, among others - and adopt instead the nationalist and popular values proposed by Frelimo.

As a result, the ideas of the enemy and of the new man came together in Frelimo's pursuit of creating a "Mozambican nation." In other words, "the building of national unity and the transformation of mentalities arose as two sides of the same coin, linked indissociably to the consolidation to what Machel and Frelimo called 'our area' in opposition to the 'enemy area"' (Cabaço, 2001: 106). A process in which Frelimo managed to secure its role as the sole power in Mozambique by claiming to be "the heirs of the tradition of resistance and the legitimate representatives of the Mozambican people from Rovuma to Maputo" (Machel, 1982).

In this context, the Meeting of the Compromised helped to materialize those logics in different ways. As indicated before, by exposing people's past misdeeds, this event allowed Frelimo to identify who was with them and who was not. ${ }^{16}$ Meanwhile, this mechanism also reinforced the logic of transformation required by Frelimo in their attempt to mentally decolonize the compromised. All in all, as this process allegedly separated the wheat from the chaff and guided people's transformation, it helped Frelimo to build on the ideas of saviors and founders of Mozambique, cornerstones of what was later known as the "liberation script" - the hegemonic tale that narrates how the country was freed from Portugal's colonial grip (Borges Coelho, 2013).

\section{The end of the civil war: The continuing remembering of the liberation war}

The struggle continued and assumed different forms and directions as oppositional forces were present not only inside, but also outside the country. Evidence suggests the existence of an armed movement against Frelimo as early as 1976, only a few months after independence (Chichava, 2018). Frelimo had then a new "enemy" to fight against, Renamo or the "armed bandits," as Frelimo commonly characterized them. ${ }^{17}$ Renamo initially enjoyed the support of former Rhodesia and later of the Apartheid regime in South Africa, which was used by Frelimo to portray the armed conflict as an extension of the war of external aggression, and, as such, a war of destabilization (Hanlon, 1990; Vines, 1991). ${ }^{18}$ Conversely, by calling attention to the authoritarian regime and repressive policies undertaken by Frelimo, Renamo labeled it a war for democracy.

Whether a war of destabilization, a war for democracy, or both, the fact is that the war "pitted from the start and in its overwhelming majority members of the same national communityMozambicans against Mozambicans" (Morier-Genoud et al., 2018: 2), and its end, in 1992, opened another window of opportunity for change. Unlike in other contemporaneous cases such as El Salvador and Rwanda, where the United Nations (UN) pushed for the implementation of mechanisms to investigate and bring to justice the responsible for the violations of international humanitarian law, such demand was absent in Mozambique. The prevailing discourse in the country was 
that of forgiveness and of leaving the past behind (Bueno, 2019b). Instead of enmity, political leaders expressed their hopes of a harmonious and inclusive future. The following declaration of the leader of Renamo at the time, Dhlakama, during the negotiations with Frelimo serves as an example:

Renamo wants a genuine negotiation conducive to national reconciliation without victors or vanquished and without recrimination followed by constitutional reform; to unite efforts in order to form a new Mozambique where brotherhood will be affirmed by free debate of ideas and decision of consensus; a new Mozambique where armed struggle need never be the last and only resort for the solution of our problems (Dhlakama, 1989) (emphasis added by the author).

The Mozambican political leaders chose amnesty as the TJM that would materialize national reconciliation. "Amnesty transforms them [referring to Renamo] into normal people and considers them free from guilt" (Chissano, 1989: 5), argued Chissano in favor of this mechanism. The understanding therefore was that amnesty would allow old enemies to become normal people and that together they would form a new Mozambique. In this context, following the signing of the GPA between both sides, the Frelimo-led government enacted Amnesty Law 15/92 on 14 October 1992. "Within the principle of national reconciliation and harmonization of the life of the Mozambican people" (BR, 1992), this law exempted members of both sides from the crimes and abuses committed from 1979 to 1992. Following the principles of the GPA, Renamo became a political party (UN, 1992: 5) and participated in the general elections in 1994. Meanwhile, the majority of ex-combatants were demobilized and reintegrated into Mozambican society under the auspices of the UN (Pardoel apud Borges Coelho, 2002).

Besides Renamo's political accommodation, the first post-civil war decade also witnessed the emergence of new versions about Mozambique's past that either added nuances or directly challenged the official narrative, or the liberation script, reproduced by Frelimo. Such new versions could possibly be termed counter-memories as they contradicted Frelimo's narrative of the past (Neves de Souto, 2013), bringing to light the life stories of figures deemed traitors by Frelimo. ${ }^{19}$ At the same time, Frelimo 'quieted down' the memories of its heroic past and gave prominence to the need to reshape the party's ideological and economic discourse in light of Mozambique's new realities, a multiparty and capitalist systems (Neves de Souto, 2013).

Yet, despite this emergence of new voices and soothing of Frelimo's heroic past, a full reformulation of memory narratives did not hold. Particularly during general elections, Frelimo has repeatedly resorted to old pejorative labels — such as "armed bandits" — as well as to memories of the armed conflict to discredit and accuse Renamo (Savana, 2003a: 3). Several declarations of the late leader of Renamo have also emphasized Frelimo's dictatorial past. As the citation below shows, more than 10 years after the end of the armed conflict, Dhlakama still recalled the ill-treatment received during the peace negotiations as well as blamed Frelimo for the crimes of the civil war.

According to Dhlakama, Frelimo has always denied implementing democracy, 'that is why the war lasted 16 years.' 'Samora Machel [. . .] and Joaquim Chissano, then Foreign Minister, told the invited bishops that they did not want to negotiate with bandits and wild boars'. Dhlakama [also] accused Frelimo of being responsible for the massacre of about one million people during the armed conflict (Savana, 2003b: 4).

This means that in spite of the calls for reconciliation Frelimo and Renamo have continued to rely on their own (competing) versions of the past. On the one hand Frelimo's authorities still characterize the civil war as a war of destabilization, whereas on the other hand Renamo still portrays it as a war for democracy. ${ }^{20}$ Not long ago, the Renamo deputy Ivone Soares resorted to such 
a narrative in one of her speeches in the national assembly: "the war for democracy, which began in 1977, was imposed on us by Frelimo because it left no alternative to the Mozambican people. Any attempt of opposition to the system imposed by the Front was violently repressed [. . .]" (Savana, 2014: 10) (emphasis added by the author).

While there are no guarantees that other TJMs - such as a truth commission or a tribunalwould have led to a different result, the fact is that in the presence of amnesty, Frelimo and Renamo have continued to wage their war with memories as weapons (Igreja, 2008). But rather than a 'memory deadlock,' one could argue that Renamo has never managed to question Frelimo's legitimacy_related to its role in the liberation war-nor its nationalist foundation (Brito, 2009: 7). At the same time, Frelimo has kept the old logic of 'the enemy' alive within which Renamo has taken over from the Portuguese colonialism, the Rhodesian racism, and the South African racism as the main character.

Moreover, Frelimo has revitalized the liberation war narrative through the implementation of different policies and measures. In 2008, for instance, the government of the former president Armando Guebuza marked the 40th anniversary of the deaths of the liberation war heroes who had died in $1968 .^{21}$ In one of the several speeches Guebuza gave that year, he asserted: "Mozambique is a true Homeland of Heroes. We all should be proud of this fact, in the present and in the future" (Matusse et al., 2015: 14). He then continued his speech by listing the names of all heroes that had already been honored during 2008. As expected, these were all names of former Frelimo combatants who had participated in the liberation war. ${ }^{22}$ Not limited to 2008 , other ceremonies were also held in the coming years. ${ }^{23}$ An important feature of those ceremonies was that they were organized in different localities, usually in the birthplaces of those ex-combatants. This has allowed Frelimo to continuously reactivate the memories of the liberation war throughout the country and in somewhat isolated zones.

This celebratory remembering of the liberation war also included the publication of ex-combatants biographies by the Instituto de Investigação Sócio-Cultural (ARPAC) ${ }^{24}$ Responsible for publishing dozens of books about the life stories and deeds of liberation war combatants, such endeavor has been "one of the highest impact projects developed by ARPAC" (ARPAC) at the request of the Frelimo-led government. ${ }^{25}$

Mozambique's sites of memory also dictate who and what is to be remembered in the country. To celebrate the 40th anniversary of his death, Frelimo declared 2009 the year of Eduardo Mondlane. To honor the memory of the "architect of the national unity," as Mondlane is characterized by allegedly bringing together the minor movements that formed Frelimo, the government built a museum in Nwadjahane, Gaza province, Mondlane's birthplace. ${ }^{26}$ Frelimo has also promoted the memorialization of Samora Machel. The party declared 2011 as Machel's year, marking the 25th anniversary of his death in an airplane crash in Mbuzini, South Africa. In the same year, a $9 \mathrm{~m}$ tall statue of the "father of Mozambique," as he is known, was laid in the main square of the capital Maputo, Praça da Independência. "This statue was built by the Mansudae Overseas Project, in Pyongyang, North Korea, and weights 4.8 tons" (Bueno, 2019a). Besides this statue, Armando Guebuza ordered the construction of 11 more to be placed in the provincial capitals of the country (Savana, 2011: 4).

While reproducing its own narrative of the past, Frelimo has also hindered the attempts of memorialization of its counterparts. In 2007, for instance, Renamo presented a proposal to the Municipal Assembly to attribute the name of André Matadi Matsangaíssa to a square located in one of Beira's neighborhoods (Bueno, 2019a). Renamo's supporters consider Matsangaíssa the founder of the movement and admire him for initiating the guerrilla movement against Frelimo. As Renamo had the majority in the Assembly, it secured the naming of the square. Frelimo reacted accusing Renamo of abuse of power and made several attempts to overrule the process (Savana, 2007: 2). 


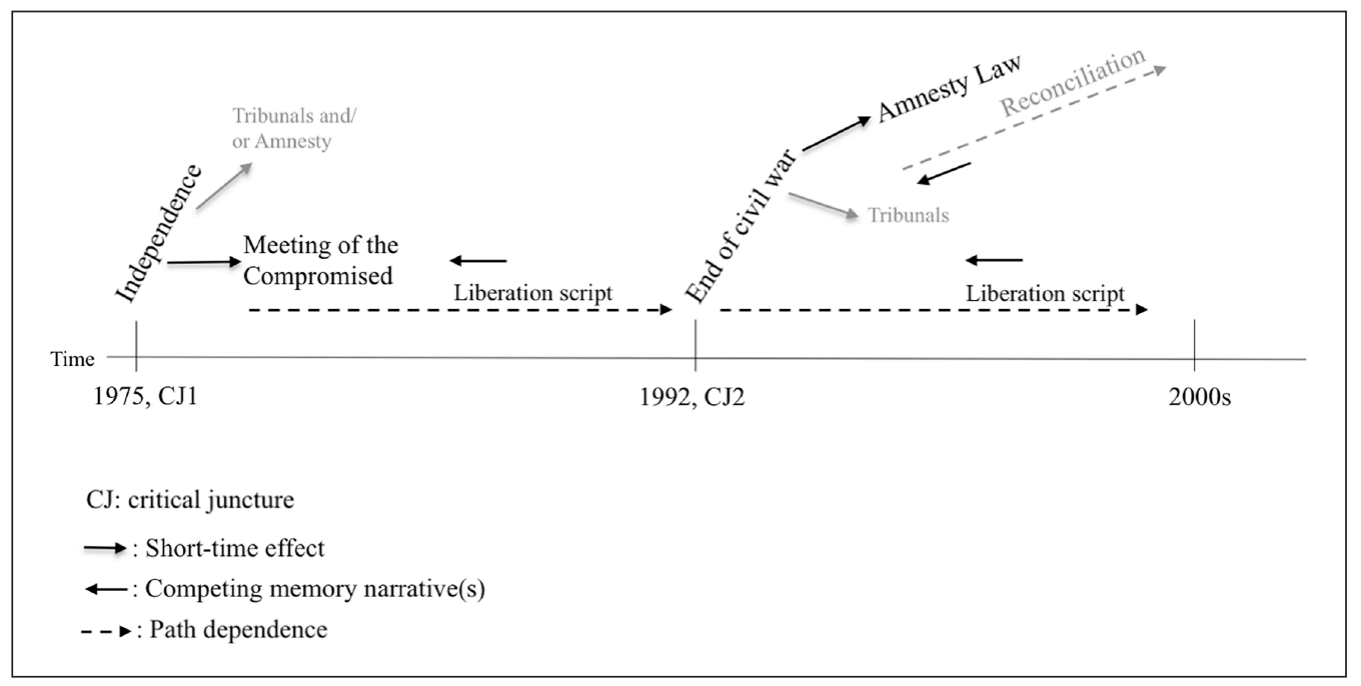

Figure 2. Mozambique's memory narratives across time. Source: Elaborated by the author.

Figure 2 above graphically illustrates this analysis. The independence in 1975 represents Mozambique's first critical juncture and it was in this context that a quasi-truth commission helped to shape the liberation war memory narrative, or the tale later known as the liberation script. Years later, a second critical juncture irrupted with the end of the civil war in 1992. In spite of this, one observes that in the context of amnesty the transformation of memory narratives did not materialize. At the end, the inertia of the liberation war narrative and its inherent legitimizing power - set in motion decades before - triumphed, overpowering any alteration of direction.

\section{Conclusion}

Previous studies connecting the fields of TJ and memory studies have called attention to the role of critical junctures on memory narratives shifts and development. Building on the case of Mozambique, the present analysis advances this literature by adding path dependence to the TJ and memory equation.

After independence, political leaders in Mozambique came against the great challenge of dealing with those who had allegedly betrayed Frelimo by helping the Portuguese during colonial times. Following the end of the civil war, top political figures also had to decide what to do with those responsible for human rights abuses and war crimes. Within these critical moments, they opted for the implementation of very distinctive mechanisms: a quasi-truth commission in the first and a general amnesty in the second. This meant that while with the former great emphasis was given to revealing past misdeeds, with the latter the focus turned to leaving them behind. Yet, the same result was achieved: the celebratory remembering of the liberation war. A narrative that has become hegemonic, helping Frelimo to legitimate its dominant status for more than four decades.

While advancing the study of the Mozambican case, this finding bears relevance to other cases as well with relative importance to the ones created in the aftermath of anti-colonial wars. This analysis shows that for understanding sequencing in the case of TJ and memory is crucial to take into account not only the elements that favor narratives shifts but also the ones that condition their continuities, critical junctures and path dependence, respectively. As such, this theoretical 
framework can inform new research in different ways. One way can be by helping scholars to understand how memory narratives develop across time whether assuming a path-dependent trajectory like in the present analysis or not. Another way can be by allowing researchers to determine the variations memory narratives that assume path-dependent trajectories experience as a result of memory entrepreneurs' struggles within moments of critical junctures. All in all, by contributing to identify continuities and/or changes in those different levels of analysis, this framework can foster the debate about TJ and memory in societies with violent pasts.

\section{Acknowledgements}

I am grateful to the Center for African Studies at Eduardo Mondlane University for the institutional support during my fieldwork missions in Mozambique. I would also like to express my gratitude to the staff members of the Mozambique Historical Archives for helping me to navigate the Archives' collections during my research. This article also benefitted considerably from presentations at the University of Birmingham, on 29 April 2019, at the University of Southampton, on 6 December 2019, and at the Center for African Studies (CEA) at Eduardo Mondlane University, on 26 February 2020. Bruno Sena Martins, Carlos Fernandes, Roberta Holanda Maschietto, Sérgio Chichava, and Vasco Martins offered insightful comments. Lastly, I am especially indebted to the two anonymous reviewers for their valuable comments on my original submission.

\section{Declaration of conflicting interests}

The author(s) declared no potential conflicts of interest with respect to the research, authorship, and/or publication of this article.

\section{Funding}

The author(s) disclosed receipt of the following financial support for the research, authorship, and/or publication of this article: The research leading to these results has received funding from the European Research Council (ERC) under the European Union's Horizon 2020 research and innovation programme (Grant Agreement $N^{o}$ 715593: 'CROME - Crossed Memories, Politics of Silence: The Colonial-Liberation Wars in Postcolonial Times').

\section{ORCID iD}

Natália Bueno iD https://orcid.org/0000-0003-0461-0087

\section{Notes}

1. On the subject of sequencing see, for example, Dancy and Wiebelhaus-Brahm (2015), Dukalskis (2011), and Olsen et al. (2010).

2. On 7 September 1974, the Portuguese government and Frelimo, in the person of Samora Machel, signed the Lusaka Accord in which Portugal formally recognized the right of the Mozambican people to independence. For further detail about the Accord see http://www1.ci.uc.pt/cd25a/wikka.php?wakka=descon06 (accessed 15 December 2019). Moreover, for an overview of the liberated zones during the liberation war see e.g. Adam (2001).

3. In his book The Struggle for Mozambique, the first president of Frelimo Eduardo Mondlane gives details about the alleged foundation of Frelimo on 25 June 1962 in Dar es Salaam. Yet an unofficial version suggests the possibility that Frelimo had been founded in Acra as former president Joaquim Chissano reminded us in his declaration in 2012. On the subject, see https://noticias.sapo.mz/actualidade/artigos/ chissano-acusa-nacionalistas-de-terem-tentado-puxar-o-tapete-a-mondlane (accessed 9 July 2019).

4. Besides PIDE and the Portuguese colonial army, people that had been connected to the following organizations or groups were also considered compromised: ANP (National Popular Action Party), GE, GEP (Special Parachutes Groups), madrinhas de guerra, comandos, flechas (a special group of counter-guerrillas within PIDE), local administrators, régulos, sipaios, agentes da Psico-Social, and members of 
puppet parties (Machel, 1982). On the Africanization of the Portuguese colonial army see, for example, Matos Gomes (2013).

5. On the subject see also, for example, Bertels (1983), Borges Coelho (2003), Igreja (2010), and Meneses (2016).

6. I follow the definition of truth commission suggested by Hayner (2011: 11-12), which prescribes that "a truth commission (1) is focused on past, rather than ongoing, events; (2) investigates a pattern of events that took place over a period of time; (3) engages directly and broadly with the affected population, gathering information on their experiences; (4) is a temporary body, with the aim of concluding with a final report; and (5) is officially authorized or empowered by the state under review." Following this definition, the Meeting of the Compromised seems to fulfill all defining elements of a truth commission except for items 3 and 4. Regarding number 3, it dealt only with "the alleged Mozambican collaborators, while excluding Portuguese officials and any investigation of the alleged crimes committed by Frelimo prior to and after independence" (Igreja, 2010: 787). Moreover, even though it was a temporary body, it did not produce a final report. To denote therefore this 'incompleteness' of the Meeting of the Compromised, it is defined as a quasi-truth commission. The characterization of the Meeting of the Compromised as a quasi-truth commission is not entirely new as a similar approach was used by Meneses (2016: 155) who defined the Meeting as a "truth-seeking commission." Lastly, leaving questions of truth and justice aside, the fact that this quasi-truth commission was one-sided makes its analysis all the more important. Whether it was intentional or not, the one-sidedness of this process shows how by accounting for just one part of the stories, Frelimo had carefully chosen what was to be remembered and what was to be forgotten.

7. There is still no consensus among scholars regarding the origins of the civil war. For discussions of this debate see, for example, Geffray (1991), Hanlon (1990), Igreja (2008), Morier-Genoud et al. (2018), Pereira (2006), and Vines (1991).

8. As Cardina (2018: 203) states, "counter-memories are not only defined as different and subaltern in relation to certain dominant memories, but as capable of challenging the topics through which certain readings have become hegemonic." For a different categorization of memory such as "strong" or "weak" see, for example, Traverso (2007: 86-88).

9. I concur with Mallinder (2008), Olsen et al. (2010), among others, on their view of amnesty laws as a mechanism of transitional justice. Yet it is important to acknowledge that such an understanding is not consensual in the literature. For discussions of this debate see, for example, Freeman (2009) and Sriram (2004).

10. Studies about memory have focused on different levels such as personal, community and national, and spheres such as social, economic, political and cultural. As indicated, the present study focuses on the political sphere, examining the role of political leaders as agents of politics of memory. That is to say that even though to examine the interconnections between those different levels and spheres is beyond the goal of this work, it advances some of these processes - see, for instance, notes 19, 20, and 26. Future research should address such interconnections as well as their combined effects. On the use of memory on the community level, and political and economic spheres in Mozambique see, for example, Pitcher (2006) and Rantala (2016).

11. On the ex-political prisoners see, for example, Meneses (2016), Neves de Souto (2013), and West (2003).

12. Despite its later contradictions (Cabaço, 2001: 108), the New Man project also included women as an active member. For further information about the role of women in the liberation war and more broadly in Mozambican society see, for example, Casimiro (1999, 2001) and Machel (1974).

13. During the liberation war, different definitions of "the enemy" emerged among Frelimo members. In his memoirs of the liberation war, the former combatant Raimundo Pachinuapa suggests that during the preparations of the II Congress of Frelimo in 1968 emerged two distinct lines inside Frelimo. The ones led by Uria Simango that argued the white was the enemy, and the others led by Eduardo Mondlane who understood that the enemy was the colonial system (Pachinuapa, 2009: 45).

14. In the original Portuguese: A luta continua!

15. For a detailed discussion on the post-independence internal enemy, portraited as the cartoon figure Xiconhoca, see, for example, Buur (2010) and Meneses (2015). 
16. As Borges Coelho (2003: 191) notes, this strategy of transforming the compromised based on guilt, repentance, punishment, and reeducation has resulted in a process of entropy that produced an undetermined — but seriously large — number of former combatants fleeing the new order, avoiding surrendering to the new authorities, or fleeing the reeducation camps to cross borders and join the forces that would soon challenge the new Mozambican authorities from South Africa and especially from Rhodesia.

17. Frelimo also named Renamo as "'fifth columnists', 'marionettes', 'proxies', or 'apartheid contras"” (Morier-Genoud et al., 2018: 2). On the subject see also Minter (1994).

18. This narrative was reinforced by the media, academic studies, as well as by reports produced by foreign governments such as the well-known Gersony report. Those vehicles "represented the war as a Manichean conflict in which the government and the socialist regime were portrayed as the defenders of sovereignty and the popular will, and Renamo as the arm of foreign interests, especially the former colonizing power, Portugal, and the South African apartheid regime" (Savana, 1998: 16).

19. Barnabé Ncomo's work serves as an example. The author challenges Frelimo's version which has labeled Uria Simango, former founding member of Frelimo, as traitor by arguing instead that he was a true nationalist. The opening page of his book states: "the story of the painful political trajectory of a revolutionary missionary whose commitment and dedication to the cause of the liberation of his people has been denied by the collective memory of his country's recent history" (Ncomo, 2003).

20. The following examples illustrate how Frelimo and Renamo have relied on their competing narratives of the civil war over the years: "I want, we want real democracy, true [democracy], the one in which people decide their future, not the democracy of some, as the Frelimo government wants. That's why we fought! This is mine, our dream!" (Dhlakama, 1994: 4); "Although [. . . Joaquim Chissano tries to identify himself as the best democrat in the country, he has never known, and neither could hide from his eyes that he still remains the president of the Frelimo Marxist-Leninist fanatics. It constitutes a major threat to peace and democracy, which must be vigorously denounced by all citizens at all levels [. . .]" (Dhlakama, 1997: 21); "According to Guebuza, this was a "war of destabilization" since, in his words, a civil war arises when citizens of the same country go to war after failing to reach consensus on a particular matter" (Savana, 2009: 3); "They say they were opposing communism, dictatorship, but this war of destabilization begins just 6 months after independence, and [they] had not seen how Frelimo was going to rule" (Chissano, 2012: 16).

21. This process of recollection and celebration of Frelimo heroes had been officially launched 2 years earlier, on 10 October 2006, "with the tribute to the first Head of the Department of Security and Defense, Filipe Samuel Magaia, murdered by enemy bullets inside Niassa." (Matusse et al., 2015: 186).

22. The names listed were the following: John Issa, Tomás Nduda, Mateus Sansão Muthemba, and João Macamo. Moreover, during 2008, Frelimo also held ceremonies to honor Josina Machel, Paulo Samuel Kankhomba, as well as to mark the 75th birthday of Samora Machel had him been alive (Matusse et al., 2015).

23. The inauguration of the monument to honor Eduardo Mondlane in Nwadjahane in June 2009, the celebration of the 75th birthday of Samora Machel in Chilembene in September 2008, the inauguration of the Samora Machel statue in Nampula in 2011, among other events.

24. ARPAC is a public institution under the auspices of the Ministry of Culture and is responsible for promoting activities to preserve the national cultural heritage and conduct research about Mozambique's history and cultural diversity.

25. Some of the ex-combatants who had their biographies written by ARPAC are: John Issa (2008), Mateus Sansão Muthemba (2008), Tomás Nduda (2008), José Pahlane Macamo (2008), Paulo Samuel Kankhomba (2008), Belmiro Obadias Muianga (2010), Robati Carlos (2012), Romão Fernandes Farinha (2013), Francisco Orlando Magumbwa (2013), Armando Tivane (2013), Luís Joaquim José Mara (2013), Francisco Manyanga (2013), Emília Daússe (2014), Samora Machel (2014) Bernabé Adissone Kajika (2014), Milagre Sebastião Mabote (2016), Filipe Samuel Magaia (2017). Far from exhaustive, this list does not include other books published by ARPAC about specific moments or events held during the liberation war such as the II Congress of Frelimo (1968). For further information on these publications, see ARPAC's website (http://www.arpac.gov.mz/index.php) and Neves de Souto (2013). Besides those books produced by ARPAC, one also observes the publication since 2001 of numerous autobiographical 
texts in the country, which "while seeking to incorporate a charge of subjectivity into the discourses they record, converge in the effort to consolidate the official macronarrative [about the liberation war]" (Chaves, 2019).

26. An open-air museum, Mondlane's historical site includes the house where he was born in 1920, the house where he stayed during his visit to the country in 1961 after years of living abroad, and a memorial with a detailed account of his life achievements, among other buildings. The author visited the museum in April 2019. For an overview of Mondlane's life story see, for example, Cruz e Silva (1998).

\section{References}

Abbot A (2001) Time Matters: On Theory and Method. Chicago: University of Chicago Press.

Adam Y (2001) Samora Machel and Mozambique's development. In: Sopa A (ed.) Samora, Man of the People. Maputo: Maguezo, pp.37-42.

Aguilar P (2002) Memory and Amnesia: The Role of the Spanish Civil War in the Transition to Democracy. New York: Berghahn Books.

Allier E and Crenzel EA (2015) The Struggles for Memory in Latin America: Recent History and Political Violence. New York: Palgrave Macmillan.

Andrews M (2003) Grand national narratives and the project of truth commissions: A comparative analysis. Media, Culture \& Society 25(1): 45-65.

Bertels I (1983) Treatment for Traitors. Documentary. Netherlands, Mozambique.

Boletim da República (BR) (1992) I Série - Número 42. Quarta-feira, 14 October.

Borges Coelho JP (2002) Antigos soldados, novos cidadãos: A reintegração dos desmobilizados de maputo. Estudos Moçambicanos 20: 141-236.

Borges Coelho JP (2003) Da violência colonial ordenada à ordem pós-colonial violenta. Sobre um legado das guerras coloniais nas ex-colónias portuguesas. Lusotopie 10: 175-193.

Borges Coelho JP (2013) Politics and contemporary history in Mozambique: A set of epistemological notes. Kronos 39(1): 10-19.

Brito L (2009) Discurso político e pobreza em Moçambique: Análise de três discursos presidenciais. Paper presented to II Conferência do IESE, "Dinâmicas da Pobreza e Padrões de Acumulação em Moçambique", Maputo, Mozambique, Abril.

Bueno N (2019a) 'Marginalization and conflict - The politics of memory in Mozambique'. Justice in Conflict, 12 August 2019. Available at: https://justiceinconflict.org/2019/08/12/marginalization-and-conflict-thepolitics-of-memory-in-mozambique/ (accessed 05 January 2020)

Bueno N (2019b) Reconciliation in Mozambique: Was it ever achieved? Conflict, Security \& Development 19(5): 427-452.

Buur L (2010) Xiconhoca: Mozambique's ubiquitous post-independence traitor. In: Thiranagama S and Kelly T (eds) Traitors: Suspicion, Intimacy, and the Ethics of State-Building. Philadelphia, PA: University of Pennsylvania Press, pp.24-47.

Cabaço JL (2001) The new man (brief itinerary of a project). In: Sopa A (ed.) Samora, Man of the People. Maputo: Maguezo, pp.103-112.

Cardina M (2018) Deserção de antigos oficiais alunos da Academia Militar (1970). In: Cardina M and Sena Martins B (eds) As Voltas do Passado. A Guerra Colonial e as Lutas de Libertação. Lisboa: Tinta da China, pp.198-204.

Cardina M and Martins BS (2019) Memorias cruzadas de la guerra colonial portuguesa y las luchas de liberación africanas: Del Império a los estados postcoloniales. ÉNDOXA: Series Filosóficas 44: $113-134$.

Casimiro I (1999) "Peace on earth, war at home" feminism and women's organisations in Mozambique. Dissertation elaborated for a Master's Degree in Sociology, Faculty of Economics, Coimbra.

Casimiro I (2001) Rethinking the relations between woman and man during the time of Samora. In: Sopa A (ed.) Samora, Man of the People. Maputo: Maguezo, pp.95-102.

Chaves R (2019) Autobiografias em Moçambique: A escrita como monumento (2001-2013). Revista História (São Paulo) 178: 1-22. 
Chichava S (2018) The anti-frelimo movements \& the war in Zambezia. In: Morier-Genoud E, Cahen M and Do Rosário D (eds) The War Within: New Perspectives on the Civil War in Mozambique, 1976-1992. New York, NY: Boydell and Brewer, pp.17-45.

Chissano J (1989) Press Conference, 17 July 1989. Available at: http://www.mozambiquehistory.net/history/ peace process/89/07/19890717 press conference.pdf (accessed 20 May 2019).

Chissano J (2012) Pena que não continuemos a ter campos de reeducação. Savana, 05 May.

Collier R and Collier D (2002) Shaping the Political Arena: Critical Junctures, the Labor Movement, and Regime Dynamics in Latin America. Notre Dame, IN: University of Notre Dame Press.

Conley B (2019) Memory from the Margins: Ethiopia's Red Terror Martyrs Memorial Museum. Cham, Switzerland: Palgrave Macmillan.

Cruz e Silva T (1998) The Influence of the Swiss mission on Eduardo Mondlane (1930-1961). Journal of Religion in Africa 28(2): 187-209.

Dancy G and Wiebelhaus-Brahm E (2015) Timing, sequencing, and transitional justice impact: A qualitative comparative analysis of Latin America. Human Rights Review 16(4): 321-342.

Dhlakama A (1989) 16-Points Declaration, August 1989. Available at: http://www.mozambiquehistory.net/ history/peace_process/89/08/19890815_english_translation_16_points.pdf (accessed 20 May 2019).

Dhlakama A (1994) Mensagem aos moçambicanos. Savana, 12 August.

Dhlakama A (1997) Mensagem de sua Excelência, o Presidente da Renamo, Afonso Dhlakama por ocasião do fim do ano. Savana, 3 January.

Dukalskis A (2011) Interactions in transition: How truth commissions and trials complement or constrain each other. International Studies Review 13(3): 432-451.

Freeman M (2009) Necessary Evils Amnesties and the Search for Justice. Cambridge; New York: Cambridge University Press.

Geffray C (1991) A Causa das armas em Moçambique: Antropologia da Guerra Contemporânea. Porto: Afrontamento.

Hanlon J (1990) Mozambique: The Revolution Under Fire. London: Zed Books.

Hanlon J (1991) Who Call the Shots? Bloomington, IN: Indiana University Press.

Hayner PBB (2011) Unspeakable Truths: Transitional Justice and the Challenge of Truth Commissions. New York: Routledge, pp.1-356.

Igreja V (2008) Memories as weapons: The politics of peace and silence in post-civil war Mozambique. Journal of Southern African Studies 34(3): 539-556.

Igreja V (2010) Frelimo's political ruling through violence and memory in postcolonial Mozambique. Journal of Southern African Studies 36(4): 781-799.

International Herald Tribune (IHT). Chinese-style public shaming. Subtle Mozambican force used on excollaborators, 9 March 1979.

Jelin E (2003) State Repression and the Labors of Memory. Minneapolis, MN: University of Minnesota Press.

Lessa F (2013) Memory and Transitional Justice in Argentina and Uruguay: Against Impunity. New York: Palgrave Macmillan.

Machel S (1974) A Luta Continua. Porto: Afrontamento.

Machel S (1975) The people's republic of Mozambique: The struggle continues. 25 June 1975.

Machel S (1982) Descolonização mental é o nosso problema actual. Notícias, 11 May.

Mahoney J (2000) Path dependence in historical sociology. Theory and Society 29(4): 507-548.

Mallinder L (2008) Amnesty, Human Rights and Political Transitions: Bridging the Peace and Justice Divide. Oxford: Hart.

Matos Gomes C (2013) A africanização na guerra colonial e as suas sequelas. Tropas locais - os vilões nos ventos da História. In Meneses P and Martins Bruno S (eds) As Guerras de Libertação e os Sonhos Coloniais: Alianças Secretas, Mapas Imaginados. Coimbra: Almedina, pp.123-142.

Matusse R, Malique J and Issufo J (2015) Moçambique - Pátria de Heróis: Colectânea de Comunicações do Chefe de Estado (2005-2014). Maputo: Gabinete de Imprensa da Presidência da República.

Meneses MP (2015) Xiconhoca, o inimigo: Narrativas de violência sobre a construção da nação em Moçambique. Revista Crítica de Ciências Sociais 106: 9-52. 
Meneses MP (2016) Hidden processes of reconciliation in Mozambique: The entangled histories of truthseeking commissions held between 1975 and 1982. Africa Development 41(4): 153-180.

Minter W (1994) Apartheid's Contras: An Inquiry into the Roots of War in Angola and Mozambique. London: Witwatersrand University Press.

Morier-Genoud E, Cahen M and Do Rosário D (2018) Introduction: The civil war in Mozambique A history still to be written. In: Morier-Genoud E, Cahen M, and Do Rosário D (eds) The War Within: New Perspectives on the Civil War in Mozambique, 1976-1992. New York, NY: Boydell and Brewer, pp.1-14.

Ncomo BL (2003) Uria Simango: Um Homem, Uma Causa. Maputo: Novafrica.

Neves de Souto A (2013) Memory and Identity in the history of Frelimo: Some research themes. Kronos 39: 280-296.

Notícias (1982a) Comprometidos ou compatriotas? - Presidente Samora Machel convida colaboracionistas a optarem. Notícias, 11 May.

Notícias (1982b) Reintegração de moçambicanos comprometidos. Direcção do Partido promove reunião. Noticias, 04 May.

Notícias (1992) Reconciliação nacional é tarefa de todos os moçambicanos. Notícias, 05 October.

Olsen T, Payne L and Reiter A (2010) The justice balance: When transitional justice improves human rights and democracy. Human Rights Quarterly 32(4): 980-1007.

Pachinuapa RD (2009) II Congresso da Frente de Libertação de Moçambique (FRELIMO): Memórias. Maputo: R.D. Pachinuapa.

Pereira JCG (2006) A Política da Sobrevivencia: Camponeses, Chefes Tradicionais e Renamo no Distrito de Marínguè, 1982-1992. Maputo: Promédia.

Pitcher MA (2006) Forgetting from above and memory from below: Strategies of legitimation and struggle in postsocialist Mozambique. Africa 76(1): 88-112.

Rantala J (2016) 'Hidrunisa Samora': Invocations of a dead political leader in Maputo Rap. Journal of Southern African Studies 42(6): 1161-1177.

Savana (1998) Democracia, narrativa e conflito nas páginas dos "Savana" e do "Domingo". 27 November.

Savana (2003a) Ao que chegou a AR. Bombeiros e bandidos discutem assuntos da nação. 11 Abril.

Savana (2003b) Dhlakama farto de acusações dispara. "Queríamos negociar em 1982, e chamaram-nos de javalis". 24 October.

Savana (2007) Depois de Matsangaíssa, Renamo avança com mais nomes. 26 June.

Savana (2009) MARP apela ao fim dos homens armados da Renamo. 10 July.

Savana (2011) Samora retorna à Praça da Independência e Graça manda recados. 21 October.

Savana (2014) Que venha a paz! Sabe melhor o mel e não este fel associado à polvora. 4 July.

Schafer J (2007) Soldiers at Peace: Veterans of the Civil War in Mozambique. New York: Macmillan.

Schudson M (1992) Watergate in American Memory: How We Remember, Forget, and Reconstruct the Past. New York: Basic Books.

Soifer HD (2012) The causal logic of critical junctures. Comparative Political Studies 45(12): 1572-1597.

Sokolić I (2019) International Courts and Mass Atrocity Narratives of War and Justice in Croatia. Cham, Switzerland: Palgrave Macmillan.

Sopa A (ed.) (2001) Samora, Man of the People. Maputo: Maguezo.

Sriram CL (2004) Confronting Past Human Rights Violations: Justice vs. Peace in Times of Transition. London; New York: Frank Cass.

Traverso E (2007) Historia y memoria. Notas sobre un debate. In: Franco M and Leví F (eds) Historia Reciente. Perspectivas y Desafios Para un Campo en Construcción. Buenos Aires: Editorial Paidós, pp.67-96.

United Nations (UN) (1992) General peace agreement for Mozambique. UN Doc. S/24635, 4 October.

Vines A (1991) Renamo: Terrorism in Mozambique. Bloomington, IN: Indiana University Press.

West HG (2003) Voices twice silenced: Betrayal and mourning at colonialism's end in Mozambique. Anthropological Theory 3(3): 343-365.

Wiegink N (2013) The forgotten sons of the State: The social and political positions of former government soldiers in post-war Mozambique. Colombia International 77(316): 43-72. 


\section{Author biography}

Natália Bueno is currently a Post-Doctoral Researcher at Project CROME - 'Crossed Memories, Politics of Silence: The Colonial-Liberation Wars in Postcolonial Times,' Centre for Social Studies, University of Coimbra, Portugal. Her research interests currently include transitional justice, reconciliation, colonial-liberation wars, Southern Africa and memory, and she published her work in Conflict, Security \& Development among other outlets. She is also a former visiting researcher at the Kroc Institute for International Peace Studies, University of Notre Dame, USA. Email address: nataliabueno@ces.uc.pt. 